\title{
Un muro, inusual imagen religiosa. El vocablo bhitti en Abhinavagupta
}

\author{
Óscar Figueroa CASTRo \\ Universidad Nacional Autónoma de México \\ figueroa@correo.crim.unam.mx
}

Para Mme. L. Bansat-Boudon

\begin{abstract}
RESUMEN
Este ensayo revisa el significado de una imagen poco común dentro de la literatura religiosa y filosófica de la India para describir la naturaleza última de dios y el ser humano: un muro o lienzo (sánscrito, bhitti). Debemos el uso de tan singular imagen a Abhinavagupta, el gran exegeta de la cosmovisión tántrica quien vivió en Cachemira entre los siglos X y XI de nuestra era. Tras ofrecer algunos antecedentes, la reflexión se centra en pasajes clave de la obra de Abhinavagupta y muestra cómo, lejos de ser secundaria, la imagen de un muro posee su propia forma de consistencia y poder expresivo en sintonía con las principales premisas doctrinales de nuestro autor, en especial su apuesta por una visión dinámica y en última instancia paradójica de la realidad divina, el cosmos y la salvación.
\end{abstract}

Palabras clave: Abhinavagupta, filosofía tántrica, bhitti, metáforas religiosas.

\section{A wall, unusual religious metaphor. \\ The word bhitti in Abhinavagupta}

\begin{abstract}
This paper discusses the meaning of an image rarely used within the religious and philosophical corpus of ancient India in order to describe the ultimate nature of God and the human being: a wall or canvas (Sanskrit, bhitti). The usage of such a peculiar image belongs to Abhinavagupta, the great exegete of the Tantric tradition who lived in Kashmir between the tenth and eleventh centuries A.D. After presenting some antecedents, the paper focuses on key passages taken from Abhinavagupta's work and shows how, far from being secondary, the image of a wall possesses a remarkable consistency and expressive power in accordance with Abhinavagupta's doctrinal presuppositions, in particular his commitment to a dynamic and ultimately paradoxical view of the divine realm, the universe and salvation.
\end{abstract}

Keywords: Abhinavagupta, Tantric philosophy, bhitti, religious metaphors.

SUMARIO: 1. Introducción. 2. Bhitti antes y después de Abhinavagupta. 3. Un muro, imagen de la infinitud (an-anta) de dios. 4. Un muro, imagen de la infinitud del ātman. 5. Conclusiones.

FECHA DE RECEPCIÓN: 23 DE 11 DE 2012

FECHA DE ACEPTACIÓN: 15 DE 04 DE 2013 


\section{INTRODUCCIÓN}

Abhinavagupta vivió entre los siglos X y XI en Cachemira, por entonces la capital intelectual de la India. Aunque suele identificársele como el máximo exponente de la vertiente monista (advaita) del «shivaísmo de Cachemira», en realidad su invaluable contribución a la cultura sánscrita rebasa con mucho lo que pueda evocar esta ambigua categoría, creada en retrospectiva con el fin de agrupar una amplia variedad de cultos y doctrinas de orientación tántrica. Así, su pensamiento incursionó con autoridad en ámbitos tan diversos como la dramaturgia y la poética, la estética y la epistemología, la metafísica y la teoría ritual. Más todavía, antes que una simple participación en todos estos terrenos por separado, lo que observamos es una ambiciosa tentativa de integración inspirada en una preocupación fundamental, herencia directa, como muchas otras cosas en la India, de la tradición de las Upanișads: cómo articular lingüísticamente la naturaleza última de la deidad sin detrimento de su carácter absoluto y de conformidad con los paradigmas de superioridad trascendente (param, ekatā) y superabundancia inmanente (pürnatā, sarvatā).

Entre otras estrategias, la respuesta de Abhinavagupta a este dilema está organizada alrededor de una singular apropiación hermenéutica del ritual tántrico que pone en entredicho los contornos que normalmente distinguen al rito de la especulación, al hacer del pensar. Como parte de esta apropiación, nuestro autor defenderá la idea de que la unidad absoluta de dios presupone la divinidad (y por ende la realidad) de la creación y de todos los seres que la habitan, alejándose así no sólo de los modelos dualistas sino además del monismo, más estático y menos incluyente, del Vedānta.

A fin de conciliar ambas esferas, el mundo de la diversidad y la realidad trascendente, Abhinavagupta desarrolla una doctrina inmanentista -dios deviene en las cosas y de algún modo reside en ellas - y la lleva hasta sus últimas y paradójicas consecuencias al apostar por una relación dinámica entre los planos supremo y ordinario, entre lo trascendente y lo manifiesto, entre la permanencia y el cambio, entre la identidad y la diferencia, entre lo divino y lo humano. Tal dinamismo acaba desnudando la fragilidad de éstas y cualesquiera otras determinaciones o dicotomías, y a cambio afirma el continuum creador de una divinidad supereminente que anima todas las cosas sin estar confinada a ninguna, a la que es imposible asignar una identidad fija (sea ésta figurativa, discursiva o conceptual), y que en ese sentido posee un fuerte componente apofático. Desde esta perspectiva, la meta más alta para el ser humano, su libertad (mukti), consiste en participar (desde luego, con el respaldo de una amplia variedad de prácticas y ritos, así como del legado contemplativo y yóguico de la tradición india en general) de la naturaleza dinámica y en varios sentidos lúdica de este Absoluto inasible, inyectando así dinamismo, vitalidad y poder a su propio ser o àtman.

Son varias las metáforas e imágenes que en la obra de Abhinavagupta giran alrededor de (y a su modo buscan recrear) esta superioridad gestada en el carácter indeterminado y enigmático de la realidad última. Destaca, por ejemplo, el rico imaginario asociado con el fenómeno de la luz que Abhinavagupta abraza a fin de explorar la actividad de la mente divina. Entonces, desde sus entrañas de luz (prakāśa), el Abso- 
luto emite sin cesar un torrente de finísimos filamentos incandescentes (ullāsa, sphurana, etc.), que gradualmente se transforman en pensamiento, emoción y materia, realidades también apreciadas según su inherente naturaleza luminosa $(\bar{a} b h \bar{a} s a) .{ }^{1}$ Las imágenes y metáforas asociadas con el sonido, así como con la actividad sexual y en general con diversos procesos corporales, no son menos importantes, y a menudo se entrecruzan y confunden con el rico y complejo simbolismo de la luz. ${ }^{2}$ Mucho menos conspicua en el corpus abhinavaguptiano, y una verdadera rareza dentro de la literatura especulativa de la India antigua, es la noción de «muro» (sánscrito bhitti), tema de este artículo.

\section{BHITTI ANTES Y DESPUÉS DE ABHINAVAGUPTA}

Al parecer, los primeros que llamaron la atención sobre el uso que Abhinavagupta da a la palabra bhitti fueron Masson y Patwardhan. No es casual que su fugaz alusión esté planteada en tono interrogativo - ¿alguien más, aparte de Abhinavagupta, ha comparado el alma humana (ätman) con una «pared»?, se preguntaban- ${ }^{3} \mathrm{Su}$ exigua y hasta cierto punto evasiva respuesta — «Hasta donde sabemos la palabra aparece varias veces en el Yogavāsișthamahārāmāyaṇa»- más que resolver el enigma lo hace más hondo. Pregunta y respuesta ponen de relieve un mismo hecho, a saber, lo inusual que resulta la imagen de una pared en el discurso filosófico y religioso de la India antigua.

Desde luego, el término se usa con frecuencia en un sentido no metafórico. Por ejemplo, dentro de las propias tradiciones que influyeron sobre el pensamiento de $\mathrm{Ab}$ hinavagupta, el Vijñannabhairava Tantra, breve manual del siglo IX que enseña varias formas de contemplación (bhāvanā), pide al adepto posar la mirada en vastos espacios abiertos, libres de «árboles, montañas o muros». ${ }^{4}$ Empero, repito, no es este el sentido que aquí nos ocupa.

Volviendo a Masson y Patwardhan, éstos no aclaran si la presencia del vocablo en el voluminoso y sincrético Yogavāsișthamahārāmāyaṇa, también conocido simplemente como Yogavāsiștha, ha de tomarse como un precedente y por lo tanto como el texto al que uno debiese acudir con el fin de trazar la posible historia semántica de la palabra. Al respecto es importante notar que el estudio de Masson y Patwardhan fue escrito hace casi medio siglo y el conocimiento que en ese entonces se tenía del Yo-

\footnotetext{
${ }^{1}$ Al respecto véase, por ejemplo, P. Muller-Ortega, «Luminous Consciousness: Light in the Tantric Mysticism of Abhinavagupta», en M. Kapstein (ed.), The Presence of Light. Divine Radiance and Religious Experience, Chicago/Londres, 2004, pp. 45ss.

${ }^{2}$ De hecho, el sentido técnico de varias palabras en la obra de Abhinavagupta descansa en una polivalencia semántica que remite al mismo tiempo a realidades luminosas, sónicas y eróticas. Tal es el caso, por ejemplo, de las formas derivadas de las raíces verbales sphur-, srj-, las-, div-, entre otras.

3 J. L. Masson y M. V. Patwardhan, Śāntarasa and Abhinavagupta's philosophy of aesthetics, Puna, 1969, p. 131, n. 1. Además de «pared» (wall), los autores traducen bhitti, no incorrectamente como veremos, como «lienzo» (canvas).

${ }^{4}$ Vijñānabhairava Tantra 60: nirvṛkṣagiribhittyādau deśe dṛștịn vinikșipet.
} 
gavāsiștha, ${ }^{5}$ tanto en lo que concierne a su contenido como a su redacción, ha cambiado radicalmente en la última década gracias a un exhaustivo trabajo encaminado a reconstruir su evolución textual.

En efecto, al igual que otras obras monumentales de la tradición sánscrita, por ejemplo el Mahābhārata, la composición del Yogavāsiștha, tal como hoy lo conocemos, refleja un proceso de asimilación y ampliación de diversos materiales básicos de entrada, al menos narrativamente, la historia del héroe épico Rāma-, a lo largo de varios siglos. Más exactamente, hoy está fuera de toda duda que el núcleo original del texto, redactado en Cachemira hacia los siglos X-XI en una atmósfera que hace eco de elementos budistas y otros afines al pensamiento de Abhinavagupta, ${ }^{6}$ fue sometido a un intenso proceso de redefinición e interpolación en los siglos subsecuentes. ${ }^{7}$ Ese núcleo, la recensión más antigua, corresponde al texto conocido bajo el título de Mokșopāya, mientras que, en sentido estricto, el Yogavāsiștha sería una redacción posterior que incorporó nuevos elementos, tanto narrativos como doctrinales, buscando así armonizar su contenido con las premisas de la corriente monista del Vedānta. Fue bajo esta apariencia que el texto alcanzó popularidad y fue editado en la época moderna, relegando a un segundo plano el núcleo original y confundiendo a más de un especialista.

Así las cosas, más que un antecedente, es muy probable que el uso de la palabra bhitti en la edición estándar del Yogavāsiștha tenga su origen en ese estrato más antiguo, el cual, como mencioné, presenta importantes paralelos doctrinales y léxicos con las tradiciones śaiva desarrolladas en Cachemira entre los siglos IX y XI. ${ }^{8}$ Teniendo en cuenta todas estas reservas, diré tan sólo que las incidencias de la palabra bhitti en el Mokșopaya parecen inscribirse en la doctrina principal del texto, de la que dependería entonces el sentido de aquéllas. Como apunta J. Bronkhorst, dicha doctrina consiste en un «ilusionismo que niega la realidad objetiva del mundo. El mundo sólo existe en la imaginación [...] Sólo la conciencia es real». ${ }^{9}$ Así, conforme a su muy distintiva lógica metafórica, ${ }^{10}$ el texto insistirá en que cualquier fenómeno que podamos con-

\footnotetext{
${ }^{5}$ Con base sobre todo en la opinión de V. Raghavan, «The Date of the Yogavāsiștha», Journal of Oriental Research 13 (1939), pp. 110-128, y P. C. Divanji, «The Date and Place of Origin of the Yogavāsișța», en Proceedings and Transactions of the Seventh All-India Oriental Conference, Baroda, 1935, pp. 15-28.

${ }^{6}$ Cfr. J. Hanneder, Studies on the Mokșopāya, Wiesbaden, 2006, p. 36; J. Hanneder, «Śaiva Tantric Material in the Yogavāsiștha», WZKS 42 (1998), pp. 67ss; W. Slaje, Vom Mokșopāya-Śāstra zum Yogavāsiștha-Mahārāmāyaṇa, Viena, 1994, pp. 210-213; B. Lo Turco, «Il terzo prakaraṇa dello Yogavāsișța e la dottrina śivaita della vibrazione», Rivista degli Studi Orientali 76 (2002), pp. 87ss.

${ }^{7}$ El proceso completo de redacción del texto se habría extendido entonces de los siglos X al XIII. Muchas otras versiones y compendios fueron redactadas como parte de dicho proceso, por ejemplo el Laghuyogavāsiștha.

${ }^{8}$ Desde luego una respuesta definitiva a este dilema sólo será posible una vez que concluya el trabajo de edición y análisis de los diversos estratos que componen la obra con base en los manuscritos que se han preservado, tarea a la que están consagrados los miembros del Mokṣopāya Project bajo la dirección de W. Slaje.

9 J. Bronkhorst, «Pour comprendre la philosophie indienne», en La rationalité en Asie, Lausana, 2001, p. 208.

${ }^{10}$ En lo que constituye, como bien ha notado B. Lo Turco, una profunda amalgama de discurso teórico (śāstra) y literatura (kāvya). Cfr. «The Metaphorical Logic of the Mokșopāya», en J. Hanneder (ed.), The Mokṣopāya, Yogavāsiștha and Related Texts, Aachen, 2005, en especial pp. 133-135.
} 
cebir, desde el más sublime hasta el más insignificante, no es más real que las imágenes en la mente de un pintor. El corolario lógico de la metáfora es que la conciencia suprema posee la capacidad de manifestar este universo sobre su propio lienzo o muro (bhitti). ${ }^{11}$ Ahora bien, como es de esperar dada la marcada tendencia del texto hacia el ilusionismo, algunos pasajes sugieren una irreducible diferencia ontológica entre el Absoluto per se y el lienzo donde éste plasma (imagina) el cosmos. Así, por ejemplo, en 3.15.15 leemos que, a diferencia del universo manifiesto (jagat), en el inmenso firmamento de la conciencia (cidākāśa) no tiene cabida ningún lienzo o muro (abhittimat). ${ }^{12}$ De esta guisa, los medios (upāya) para escapar a la ilusión en pos de la libertad (mokșa), estarían diseñados para trascender el fantástico pero irreal mural del dios-artista. Como veremos, Abhinavagupta resistirá la tentación del ilusionismo, dándole así un sentido distinto, a mi parecer más complejo, al término.

Desde luego, una revisión exhaustiva —en busca de antecedentes- del canon revelado producido por los diversos cultos tántricos que subyacen al pensamiento de Abhinavagupta ${ }^{13}$ rebasa con mucho el propósito de esta investigación. A manera de preámbulo diré únicamente que entre las diferentes tradiciones exegéticas que emprendieron la ardua tarea de llevar la cosmovisión revelada tántrica a la arena del debate filosófico, incorporando los avances de disciplinas como la gramática y la lógica, ${ }^{14}$ resulta pertinente referirnos al testimonio que nos ofrece Utpaladeva (siglo X), el gran pensador de la escuela del "reconocimiento" (pratyabhijña), pues en él se asoma ya el sentido que Abhinavagupta le dará a la palabra bhitti.

El término aparece una sola vez en la İ́varapratyabhijñākārikā, escolástico compendio $(k \bar{a} r i k \bar{a})$ que Utpaladeva redactó con el fin de defender la unidad y la soberanía (aiśvarya) absolutas de la conciencia divina (citi) frente a los argumentos sobre la impermanencia decretados por la vertiente idealista del budismo, el Vijñānavāda, sobre todo en la figura de Dharmakīrti (siglo VII). En el pasaje en cuestión, Utpaladeva subraya lo fútil que resulta acudir a las distintas vías de conocimiento (pramāna) para arrojar luz sobre una deidad que tiene como atributos principales precisamente la omnisciencia y la luminosidad (prakāśa). En una imagen muy socorrida tanto por Utpaladeva como por Abhinavagupta, proceder de esa manera sería tanto como querer iluminar el Sol con una lámpara. Desde esta perspectiva, en realidad Dios precede o subyace siempre a cualquier forma de conocimiento; él es el verdadero sujeto de conocimiento (pramātr) detrás de todo acto cognitivo, lo que justifica la analogía (upamā) con un muro uniforme, estable (samabhitti), sobre cuya superficie (tala) aparece plasmada como una pintura (citra) la colorida pluralidad de

\footnotetext{
${ }^{11}$ Así interpreta el exegeta Bhāskarakaṇtha (siglo XVII) varios pasajes. Cfr. por ejemplo su comentario ad 2.17.28, 3.9.24 o 4.18.42, en la edición de W. Slaje, Bhāskarakaṇthas Mokṣopāya-T̄ikā, 3 vols., Graz, 19931996.

${ }^{12}$ Bhāskarakaṇtha glosa abhittimat como la «no proliferación de seres vivos y demás» criaturas y objetos que pueblan esta creación (jīvādiprapañcah [...] tadrahitam). En otras ocasiones, el texto emplea en este mismo sentido nirbhitti (cfr. por ejemplo 2.17-18). Sigo la edición crítica de W. Slaje et al., Mokșopāya, 3 vols., Wiesbaden, 2011-2012.

${ }^{13}$ Esto es, el legado escritural de las tradiciones Kaula, Trika y Krama, entre otras.
} 
este universo (viśvavaicitrya). ${ }^{15} \mathrm{Al}$ respecto, Utpaladeva nunca sugiere que tal función sea secundaria o posea un dejo de ilusión. De hecho, como insiste I. Ratie en su imponente estudio sobre la filosofía pratyabhijña a, con la comparación Utpaladeva busca ilustrar el principio de simultaneidad dinámica que, al interior de la conciencia absoluta, gobierna la relación entre identidad y diferencia, entre Dios y su manifestación. ${ }^{16}$

Como mencioné antes, aunque menos conspicua si se la compara con otras metáforas, la noción de bhitti posee en Abhinavagupta su propia forma de consistencia y fuerza expresiva. En primer lugar porque aparece en las tres áreas alrededor de las cuales suele organizarse su obra: exégesis tántrica, debate filosófico y teoría estética; ${ }^{17}$ en segundo lugar, porque Abhinavagupta echa mano de ella en pasajes clave o culminantes, donde las estructuras referenciales y jerárquicas de la lógica convencional quedan rebasadas.

La importancia de la imagen puede también apreciarse a partir de que ésta fue retomada por los discípulos del gran maestro, notablemente Kșemarāja (siglo XI), así como por sus comentaristas, quienes la refieren libremente incluso al glosar textos donde Abhinavagupta no la usa. Un buen ejemplo de esto es el Paramārthas $\bar{a}-$ $r a$, escrito de juventud interpretado por el exegeta Yogarāja (siglo XI) a la luz de la doctrina posterior, madura, de nuestro autor. Así, en su comentario ad kārikā-s 1213, Yogarāja explica que «por voluntad propia», la luz suprema «manifiesta el universo entero sobre su propio muro (svātmabhitti)», de modo que entre aquélla y éste no existe ninguna diferencia. ${ }^{18}$ Más adelante, en $k \bar{a} r i k \bar{a} 77$, Abhinavagupta afirma que el Señor crea este universo multiforme a partir de su estado meditativo y en ese mismo acto reconoce que «la verdadera naturaleza de las cosas coincide ni más ni menos que con los dictados de su imaginación», ${ }^{19}$ sentencia que Yogarāja no duda en completar introduciendo el locus de la actividad imaginativa de dios, ahí donde su meditación cobra la forma de este universo, a saber, el «muro de la conciencia» (samvidbhitti).

\footnotetext{
${ }^{14}$ Me refiero a las corrientes de pensamiento que en sentido estricto dan vida al llamado shivaísmo de Cachemira, entre ellas las escuelas Pratyabhijñā y Spanda. Al respecto cabe notar que bhitti no aparece en textos fundacionales como el Śivasūtra y la Spandakārikā.

15 Íśvarapratyabhijūākārikā 2.3.15ab: viśvavaicitryacitrasya samabhittitalopame. Sigo la edición de R. Torella, The Íśvarapratyabhijñākārikā of Utpaladeva with the Author's Vrrtti, Delhi, 2002.

${ }^{16}$ I. Ratie, Le Soi et l'Autre. Identité, différence et altérité dans la philosophie de la Pratyabhijñā, Leiden, 2011, pp. 659ss. El breve apartado que Ratie dedica a bhitti se encuentra entre los pocos esfuerzos emprendidos a la fecha para comprender su significado y relevancia dentro de la obra de Utpaladeva y Abhinavagupta. Agradezco al lector anónimo que revisó este artículo por haber llamado mi atención sobre dicho apartado.

${ }^{17}$ Hace tiempo E. Gerow llamó la atención sobre la presencia de la palabra en estas dos últimas áreas, no así en la primera. Cfr. «Abhinavagupta's Aesthetics as a Speculative Paradigm», Journal of the American Oriental Society 114-2 (1994), p. 188, n. 17, y p. 193, n. 55.

${ }_{18}$ Yogarāja ad Paramārthasāra 12-13: svecchayā svātmabhittāv [...] viśvam ābhāsayati. Sigo la edición de L. Bansat-Boudon, An Introduction to Tantric Philosophy. The Paramārthasāra of Abhinavagupta With the Commentary of Yogarāja, Londres, 2011.

${ }^{19}$ Paramārthasāra 77: dhyānam anastamitam punar eșa hi bhagavān citrarūpāṇi | ș̣jati tad eva dhyānam samkalpalikhitasatyarūpatvam.
} 
De nuevo, al igual que en Utpaladeva, la imagen parece evocar un sentido de identidad entre el plano trascendente y su manifestación, parece reunir de manera decidida lo supremo y lo ordinario, poniendo así en entredicho la tesis ilusionista. ${ }^{20}$

Hasta aquí, pues, el preámbulo. Como intentaré mostrar a continuación la metáfora posee implicaciones más radicales. Para poder apreciarlas conviene mantener por ahora la acepción literal de «muro» o «pared», si bien no son incorrectas, como se infiere del pasaje en Utpaladeva que acabamos de revisar, las opciones de «lienzo» o «pantalla», ambas muy socorridas entre los estudiosos del shivaísmo de Cachemira. ${ }^{21}$

Entonces, para asomarnos a esa dimensión más radical quisiera detenerme en dos incidencias de la palabra. La primera pertenece a uno de los dos comentarios que Abhinavagupta escribió al Parātrīśika Tantra y describe la unidad del Absoluto a la luz del teísmo ritual del culto conocido como Trika; la segunda aparece en su Abhinavabhāratī, densa exégesis al Nātyaśāstra, tratado canónico sobre dramaturgia, y califica la naturaleza última del ser humano a la luz de la teoría del rasa o «sabor estético». Como veremos, el primer caso lleva al segundo y viceversa, confirmando la centralidad y consistencia de bhitti en el pensamiento de Abhinavagupta. Puesto que ambos usos se producen en el marco de reflexiones sobre otros aspectos de la obra de nuestro autor (en el primer caso la práctica del mantra; en el segundo la contemplación estética), a fin de entender de qué estamos hablando será necesario hacer algunas precisiones de carácter general.

\section{UN MURO, IMAGEN DE LA INFINITUD $(A N-A N T A)$ DE DIOS}

El Parātrīisikā-Tantra ${ }^{22}$ es un texto muy breve cuya fecha y lugar exacto de composición nos son completamente desconocidos. ${ }^{23}$ Lo que en cambio sabemos es que para el siglo X había alcanzado ya un estatus canónico en Cachemira entre las ver-

\footnotetext{
${ }^{20}$ Véase en este mismo sentido Yogarāja ad Paramārthasāra 87-88; también Jayaratha (siglo XII), el otro gran comentarista de Abhinavagupta, ad Tantrāloka 3.1-3: «Por el poder de su libertad ilimitada, el Señor supremo manifiesta sobre su propia pared (svabhitti) la formidable multiplicidad que da forma a este universo como si se tratara de algo distinto a él, aunque en realidad no lo sea» (svabhittāv eva svecchayā sarvam prakāśayati [...] parameśvaro hy anargalatvalakșanasvasvātantryamāhätmyāt svātmabhittāv eva anatiriktam apy atiriktāyamānam iyad viśvavaicitryam pradarśayati iti). Sigo la edición en 12 vols. de M. R. Shastri (Shrinagar, 1918-1938).

${ }^{21}$ De hecho, la glosa que el propio Abhinavagupta ofrece a ese mismo pasaje justifica la idea de un "lienzo": "En efecto, la colorida pluralidad de este universo sólo puede manifestarse si existe una deidad suprema, hecha de luz consciente, de la misma manera como una pintura [sólo puede manifestarse si existe] un lienzo (bhitti)" (İśvarapratyabhijñāvimarśinī, vol. 2, Shrinagar, 1921, p. 123: viśvavaicitryam hi tatra parameśvare prakāśaikātmani sati bhāti yathā citram bhittau). Véase asimismo İ́sarapratyabhijñāvivṛtivimarśinī, vol. 3, Bombay, 1943, p. 163.

${ }_{22}$ Todas las referencias tanto a este texto como a la Breve exégesis (Laghuvrtti) de Abhinavagupta pertenecen a la edición de J. Zadoo (Shrinagar, 1947). Por su parte, las referencias al segundo y mucho más extenso comentario (el Vivaraṇa) que Abhinavagupta escribió a esta obra pertenecen a la edición de R. Gnoli (Roma, 1985).

${ }^{23}$ En su último verso, el texto afirma que en realidad se trata de una sección del Rudrayāmala Tantra. Abhinavagupta reconoce el nexo en su Breve exégesis (Laghuvrtti). Para los problemas que supone esta presumible pertenencia, véase T. Goudriaan y S. Gupta, Hindu Tantric and Śakta Literature, Wiesbaden, 1981, pp. 47-48.
} 
tientes especulativas del culto Trika, así llamado en virtud de su panteón triple: las diosas Parā, Parāparā y Aparā. ${ }^{24}$ Escrito a manera de diálogo entre el dios Bhairava y su consorte, las primeras estrofas del texto describen la íntima relación que guardan, por un lado, la creación (srști), y, por el otro, la Palabra primordial, asociada explícitamente con los fonemas de la lengua sánscrita. De este modo, la cosmología que enmarca la pregunta por el Absoluto se desarrolla en el texto bajo la forma de una meditación sobre el sonido sagrado. Así, el dios revela lo siguiente a la diosa:

Has de saber que esta creación (srștiti) está constituida por la secuencia fonética de A a KȘA. ¡Oh gloriosa!, no hay escritura que no describa tal secuencia como la fuente de todos los mantras y conjuros. ${ }^{25}$

Y todos los mantras, continua el texto, se reducen al șrstiti-mantra, el «mantra inmortal» (amrtamantra), formado por los fonemas $\mathrm{S}, \mathrm{AU}$ y $\mathrm{H}^{26}$ :

¡Oh hermosa!, el corazón de Bhairava se compone del tercer brahman, el cual está unido a la decimocuarta [vocal] y es penetrado por el último de los señores de las fases lunares. ${ }^{27}$

Oculta en este par de enigmáticos versos, es gracias a la exposición de Abhinavagupta que la identidad fonética del mantra sale a luz, junto con su profundo simbolismo y significado. ${ }^{28}$ Así, de acuerdo con nuestro autor, los tres fonemas que com-

\footnotetext{
${ }^{24}$ Cfr. A. Sanderson, «The Visualization of the Deities of the Trika», en A. Padoux (ed.), L'image divine. Culte et méditation dans l'hindouisme, París, 1990, p. 32; R. Gnoli (trad.), Il Commento di Abhinavagupta alla Parātrimíikā, Roma, 1985, p. xv.

${ }^{25}$ Parātrīśikā Tantra 8-9ab: amūlā tatkramāj jñeyā kṣāntā sṛștir udāhṛtā| sarveșām eva mantrānām vidyānām ca yaśasvini $\|$ iyam yoniḥ samākhyātā sarvatantreșu sarvadā.

${ }^{26}$ Al igual que otros mantras monosílabos, por ejemplo HṚịM, KLĪM o ŚR̄̄M, técnicamente SAUḤ es un mantra «seminal» (bijja), categoría idiosincrásicamente tántrica.

27 Parātrīśikā Tantra 9cd-10ab: caturdaśayutam bhadre tithīśāntasamanvitam| tṛtīyam brahma suśroṇi hṛdayam bhairavātmanaḥ. Para una descripción también codificada del mantra SAUH, véase Mālinīvijayottara Tantra 4.25 .

${ }^{28}$ Parātrīśikā Vivarana 224 (p. 262): evam etat caturdaśasu yutam saṃśliștam pañcadaśātmakam tithīśāntena visargena șoḍásenānvitam. En el mismo pasaje (241-242, p. 268), Abhinavagupta cita la descripción de SAUḤ en el Mālinīvijayottara Tantra (4.25), reconociendo su naturaleza secreta: «'Uno es el mantra seminal que contiene a la creación entera...' De ahí la prescripción de jamás ponerlo por escrito» (ekam ș̣̦țimayam bījam... iti $\mid$ ata evālekhyam pustake iti niyamah). Para descifrar el pasaje es necesario tener presente la íntima relación entre la soteriología mántrica de los Tantras y la fonética del alfabeto sánscrito. Así, que el «tercer brahman» (trityam brahma) sea S se desprende del hecho de que la palabra brahman posee un valor fonético de cinco (br-a-hm-a-n), y que este «quinteto fonético (brahmapañcaka) corresponde al grupo de las cinco sibilantes comenzando con Ś̉» (Parātrīśikā Tantra 7cd: tadūrdhvaṃ śādivikhyātam purastāt brahmapañcakam). El tercer brahman en esa serie (Ś Ș S H KȘ) es precisamente S. Ahora bien, con «decimocuarta» (caturdaśa) el texto se refiere a la decimocuarta vocal del alfabeto sánscrito: AU. La nasalización vocálica o anusvāra (representada $\mathrm{AM}$ ) y la aspiración o visarga (representada $\mathrm{AH}$ ) hacen un total de 16 vocales, a su vez asociadas con las 16 fases lunares (kalā) de la astrología tradicional india. Ḥ es el «último de los señores de las fases lunares/vocálicas» (tithisśanta) precisamente en virtud de su posición como la decimosexta vocal. Tal fase corresponde a la luna nueva o el impasse momentáneo entre el término y el comienzo de un nuevo ciclo lunar (cfr. M. Falk, «Amāvāsyā», Indian Historical Quarterly 18, 1942, pp. 26-45). Dos principios más intervienen tácitamente. Ambos se
} 
ponen el mantra reflejan la estructura ternaria de la esfera divina («el corazón de Bhairava»). Al mismo tiempo, desde el punto de vista de su secuencia, constituyen una unidad fonética inquebrantable que retrata a la deidad en su totalidad y unidad. Por secuencia se entiende aquí no sólo un principio lingüístico elemental o, antes incluso, meramente físico (el sonido viaja de manera secuencial), sino más importante aún la dimensión performativa o instrumental de los mantras, los cuales están diseñados para ser repetidos de manera continua (japa), lo que idealmente consiste en alcanzar el punto donde el flujo incesante de sonido se vuelve espontáneo, actualizando así el poder pleno del mantra, de otro modo sólo latente.

En su exégesis, Abhinavagupta despliega la relación entre las unidades individuales y el mantra como tal (su secuencia) conforme a una dialéctica de «reposo» (viśrānti) e «inclusión» (vyāpti), inspirada en la doctrina de la interrelación de todas las cosas (sarvam sarvātmakam). ${ }^{29}$ Así, cada uno de los tres fonemas representa el lugar donde la secuencia de sonido alcanza un descanso momentáneo. Esta condición es siempre relacional: para cada fonema actuar como reposo significa que el fonema subsecuente está ya involucrado en la acción de venir a reposar sobre él. De consiguiente, la noción de reposo no expresa una relación estática entre los miembros de la triada. Por el contrario, con cada reposo hay siempre implicado un sentido de actividad incesante. Por último, este dinamismo opera para los otros niveles de la estructura ternaria, no sólo como un hecho fonético. Se trata, pues, de un evento divino, no sólo desde una perspectiva teísta (cada fonema guarda una relación directa con las diosas Aparā, Parāparā y Parā respectivamente), sino, en el caso de la exégesis abhinavaguptiana, desde una perspectiva propiamente teológica y no dualista.

Desde esta perspectiva más teórica, S representa al vocablo sat («sustancia»o «esencia»), identificado con brahman, el Absoluto en la tradición del Vedānta, y de-

remontan a las doctrinas de Brāhmanas y Upanișads, aunque su articulación definitiva se debe al gramático Bhartṛhari: en primer lugar, la idea de que entre más simple es un sonido, más próximo es a la Palabra divina ( $v \bar{a} c)$. Así, los sonidos vocálicos son superiores a los consonánticos, y entre las vocales el sonido más sutil y perfecto es A. Más allá incluso de los sonidos que poseen una forma manifiesta existen sonidos más puros en virtud de su naturaleza no manifiesta o silente. Por regla general, un sonido no manifiesto escapa a toda definición, y, en este sentido, $v \bar{a} c$ misma constituye la dimensión primordial del habla en la medida en que no admite determinación alguna. Esta jerarquía a nivel de la dimensión fonética del habla en cuanto tal - la misma que daría pie a la famosa doctrina tántrica sobre los niveles del habla (catuṣpadī vāk) - se reproduce en el propio entendimiento que se tiene del valor fonético de los mantras. En segundo lugar, la relación entre un sonido sutil y uno burdo es concebida como una relación incluyente (vyāpti): un sonido puro no sólo es más próximo a la Palabra divina que uno burdo, sino que además contiene a este último. Por consiguiente, la máxima inclusión posible pertenece a la propia Palabra sagrada: estando más allá de todos los sonidos, vāc alberga todos los sonidos. Al respecto véase J. P. Brereton, «Unsounded Speech», Indo-Iranian Journal 31 (1988), pp. 1-10.

${ }_{29}^{2}$ De hecho, SAUH es la identidad mántrica de lo que Abhinavagupta, de nuevo con base en el testimonio del Mālinīvijayottara Tantra (4.25), llama la «ubicuidad de Parā» (parāvyyāpti), la ubicuidad suprema (cfr. Parātrīśikā Vivarana 124, p. 227). Aunque suele identificarse la doctrina de la interrelación de todas las cosas (sarvam sarvätmakam) con la cosmovisión tántrica, es posible hallar antecedentes en las fases tempranas de la filosofía Sānkhya, así como en la crítica jaina al dogmatismo. Al respecto véase A. Wezler, «Remarks on the sarvasarvātmakatvavāda», en R. Mukhopadhyaya (ed.), Philosophical Essays. Professor Anantalal Thakur Felicitation Volume, Calcuta, 1987, pp. 166-181. 
finido como la correspondencia recíproca entre «coseidad» (idantāa) e «inteligibilidad» (vedyatā). Por su parte, el fonema AU representa a śakti o el «poder» creador de la conciencia divina. ${ }^{30}$ De la raíz verbal $s r j-(«$ surgir») y el prefijo $v i-(« h a c i a »$, «fuera»), la visarga (H), el suave soplo que hace reverberar los sonidos vocálicos al final de una palabra, representa la fuente misma de la plenitud y libertad divinas ( $s v \bar{a}-$ tantrya); es la deidad en su aspecto no manifiesto y no obstante rico en poder creador (śaktiman). ${ }^{31}$

Si ahora volvemos a la noción de bhitti, encontramos que en su comentario al Parātrīsikā Tantra Abhinavagupta emplea la palabra justo para describir la función de H como el límite final (anta) de la actividad creadora del Absoluto:

Al estar siempre unido a AU, siempre interactuando con AU [...] el tercer brahman [es decir, S] —definido como la suma total de los objetos cognoscibles desde el punto de vista de la condición básica que subyace a su existencia misma, es decir, lo universal en la forma del ser puro-, [en última instancia] también descansa sobre $\mathrm{H}$, es decir, establece una relación continua e íntima con el límite (antah), esto es, con el «muro final» (paryanta-bhitti) de todas las fases vo-

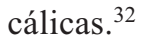

Ahora bien, que $\mathrm{H}$ es anta es exactamente lo que hallamos consignado en un pasaje posterior, donde Abhinavagupta redondea el planteamiento mediante la aposición de la forma negativa an-anta («sin fin», «ilimitado»):

El pasaje que abre diciendo «la fuente de la esencia universal», [es decir, la fuente de S], hace referencia al hecho de que tal «fuente», a saber, el ciclo supremo de poder [AU], está delimitado (anta) por Ḥ, lo ilimitado (an-anta), así llamado porque no tiene límites / porque [no] es supremo (na vidyate antah para). ${ }^{33}$

Aquí, tras establecer de nuevo la relación dinámica entre los tres aspectos de lo divino conforme a la estructura del mantra SAUH, Abhinavagupta se detiene por un momento en el hecho de que el texto revelado defina a Ḥ como «ilimitado» (an-anta),

\footnotetext{
${ }^{30}$ Cfr. Parātrīisikā Vivaraṇa 176 (p. 247).

${ }^{31}$ La palabra visarga significa además «eyaculación». Esta acepción no está ausente en Abhinavagupta; por el contrario, enriquece su teología mántrica con un simbolismo paralelo: el de la actividad sexual. Que la deidad «surja» o devenga en la forma del mundo manifiesto significa literalmente que «eyacula» ese mundo, de modo que, creado a partir del semen divino, el universo contiene la esencia (sāra) de la deidad. Desde esta perspectiva, como apunta K. M. Skora («Abhinavagupta's erotic mysticism: the reconciliation of spirit and flesh», International Journal of Hindu Studies 11, 2007, pp. 63-88), el lenguaje y el universo entero constituyen realidades eróticas o, más literalmente, espermáticas, ricas en poder seminal. Invirtiendo los términos, diríamos entonces que el acto de eyacular es un evento sónico, asociado con el valor fonético $\mathrm{H}$.

${ }^{32}$ Parātrīśikā Laghuvrtti, p. 9: caturdaśena svarena [...] yuktam satatam miśrībhütam yad idạ̣ tṛtīyam brahma [...] asphuț̄īhūtedantātmakagrāhyarāśilakșaṇam sadrūpam viśvam tat tithūsāānām pañcadaśānām svarānāạn yo 'ntah paryantabhittibhūto visargas tasmin saṃyak aviyogena anvitam viśrāntam.

${ }^{33}$ Parātrīisikā Laghuvrtti, p. 18: viśvetyādikrameṇa yat bhairavadevatācakram viśvādi, param bhairavīyam śakticakram śaktitrayarüpam tad anantasya visargasyāntah. na vidyate 'ntah paro yadapekșayā.
} 
ofreciendo para ello una glosa mínima: na vidyate antah para.${ }^{34}$ Con este paréntesis, Abhinavagupta subraya la indeterminación conceptual que conviene a la trascendencia de la deidad, indeterminación aquí descrita como «ausencia de límites» (na vidyate antah). Las cosas se tornan más complicadas, sin embargo, cuando uno trata de precisar el sentido exacto de la palabra para («superior») en la glosa. Si se la toma como un adjetivo calificando la palabra antah, entonces, aunque uno pudiera sentirse tentado a traducirla según la acepción de «otro» o «subsecuente», asumiendo entonces que Abhinavagupta interpreta an-antah en el sentido de que $\mathrm{H}$ «no tiene otro límite», o lo que es lo mismo que $H$ es el límite absoluto, resulta muy poco creíble que en un texto donde el término para desempeña un papel tan prominente en la acepción de «superior» — tanto desde una perspectiva teísta (en relación con la diosa Parā) como teológica (en relación con la idea de supremacía divina)—, la forma adjetival de la palabra en esta oración no posea también la connotación de superioridad. Así las cosas, la traducción literal resulta simplemente perturbadora: «Se dice que Ḥ es ilimitada porque no es el límite supremo».

Ahora bien, si se toma para como una glosa de segundo orden (ananta significa na anta que a su vez significa para), no cometemos un error al querer completar elípticamente la oración transfiriendo la partícula negativa de la primera glosa a la segunda: «sin límites» (na anta) significa «sin superior» (na para). Finalmente, es casi inevitable no sospechar en la oración una implicación teísta: Ḥ es ilimitada porque no es Parā, la suprema de las tres diosas. Y puesto que cada una de las diosas corresponde a cada uno de los tres fonemas, lo que tenemos es esto: $H$ no tiene límites porque no es $\mathrm{H}$, es decir, porque se niega a sí mismo en su función de límite (supremo). Aunque todo está contenido en $\mathrm{H}$, hecho que le da el carácter de máximo límite (anta), al mismo tiempo H parece liberarse de su predicación relacional. Cumple su función como límite supremo no sólo porque más allá no existe nada que lo delimite, sino porque no está delimitado por sí mismo en tanto fundamento último de la secuencia completa. H no es superior (na para) porque continuamente excede, es decir, niega, ese límite, el de la superioridad, muy a pesar de que sea justo ese atributo el que le da identidad dentro de la secuencia lineal de la triada.

¿Tenemos aquí una pista para apreciar el significado de bhitti, la imagen elegida para ejemplificar la función de $\mathrm{H}$ como el límite (anta) de todas las fases vocálicas? ¿Cumple bhitti la misma función? Mas ¿cómo puede un muro representar un límite que desconoce todos los límites? Pienso que puede esbozarse una respuesta a condición de que la metáfora sea entendida precisamente como tal, es decir, siempre y cuando no se la conceptualice.

Morfológicamente, bhitti es la forma nominal abstracta de la raíz verbal bhid-, «romper», «separar», «dividir», de modo que su acepción más básica es «partición», «división». La idea de «muro»o «pared» surge del hecho de que los muros dividen, separan. Una vez constituida semánticamente como muro y en la medida

\footnotetext{
${ }^{34}$ Glosa, por cierto, no registrada en todos los manuscritos conservados. ¿Debiéramos tomar esta irregularidad al nivel de la transmisión del texto como una indicación de una dificultad al nivel de su comprensión?
} 
en que las paredes pueden servir como el sitio para disponer o plasmar cosas sobre ellas (de ahí, por ejemplo, el término compuesto citrabhitti, «pintura mural» ${ }^{35}$ ), bhitti puede también sugerir una «superficie» o «base» (áśraya). Ahora bien, aunque esta acepción de segundo orden y más especializada pudiera representar un distanciamiento respecto a la idea original de «partición», en realidad su sentido nunca es abstracto, no por lo menos en Abhinavagupta. Bhitti no es «base» o «fundamento» en cuanto tal. Se trata más bien de una pared en esa función particular. Si ahora nos preguntamos cómo puede un muro cumplir con dicha función, la respuesta radica en el hecho de que las paredes sirven de soporte (esto es, sirven como límite o fundamento) en la medida en que permanecen indiscernibles de los trazos o texturas que sobre ellas es posible plasmar. Los muros son inmanentes a los colores, texturas y cualquier otra forma inscrita sobre su superficie. La pared como fundamento o sustrato (sub-stratum) es siempre la pared como superficie (super-face), y entonces quizá lo correcto sería hablar de un super-estrato, o en sentido inverso, de una sub-ficie.

Este par de identidades contrastantes, la pared como super-estrato y sub-ficie, se implican la una a la otra en un movimiento continuo que establece una base o fundamento y, al mismo tiempo, desestabiliza todo fundamento; que erige una estructura $\mathrm{y}$, al mismo tiempo, la echa por tierra. En este caso, la ambivalencia apunta al hecho de que el Absoluto es y no es trascendente, pues es además inmanente; significa que es y no es inmanente, pues es además trascendente. Y si como alternativa afirmamos que la deidad es trascendente e inmanente, aunque desde una perspectiva proposicional esto es correcto, la afirmación tiene el defecto de restarle importancia a la relación dinámica (no proposicional) que opera entre ambos términos, esto es, tiende a representarles, erróneamente, como categorías estables, como dos entidades: esto y aque1lo, perdiendo de vista el valor performativo o ritual de su paradójica simultaneidad: es trascendente e inmanente en la medida en que lo trascendente se transforma en lo inmanente (se niega a sí mismo) y viceversa, una y otra vez. La solución final es que no hay ni solución ni final, pues para cada uno de estos dos valores, lo trascendente y lo inmanente, resulta imposible determinar dónde comienza uno y dónde acaba el otro. Entonces, desde cierto ángulo, no es tampoco incorrecto afirmar que la deidad no es ni trascendente ni inmanente. En suma, la imagen de un muro encapsula la búsqueda abhinavaguptiana de una trascendencia que se niega a sí misma, que no tiene fin en tanto que no es el fin. ${ }^{36}$ Es en este sentido, me parece, que bhitti es en realidad una imagen apofática, cuya tarea es describir la inefable infinitud (an-anta) de dios a costa del concepto mismo de infinito.

\footnotetext{
${ }^{35}$ Cfr., entre muchos otros, Maitrāyaṇīya Upaniṣad 4.2, Mrcchakațikā 5.50, o, de nuevo, Mokṣopāya 3.4.3.

36 Todo esto muestra cuán engañoso puede resultar traducir bhitti como «base» (P. Muller-Ortega, The Triadic Heart of Siva, Nueva York, 1989, p. 213), «fundamento» (R. Gnoli, Considerazioni sull'Assoluto, Milán, 1998, p. 51), «sustrato» (R. Torella, «Una traduzione francese della Parātrimśikālaghuvṛtti di Abhinavagupta», Rivista degli Studi Orientali 54, 1980, p. 185) o «fondo» (I. Ratie, op. cit., pp. 656ss), opciones derivadas de un proceso de conceptualización que se aleja del sentido inmediato de la palabra y ahí mismo, en última instancia, oscurece el planteamiento de Abhinavagupta.
} 


\section{UN MURO, IMAGEN DE LA INFINITUD DEL $\overline{A T M A N}$}

En su erudito comentario al Nātyaśāstra, Abhinavagupta nos ofrece una clave para reconstruir las repercusiones antropológicas de su escandalosa conclusión teológica. También en este caso la metáfora elegida es un muro, bhitti, ahora usada para calificar la meta más alta a la que puede (y debe) aspirar un ser humano, a saber, el conocimiento de su esencia última o àtman, evento que coincidiría con la realización de un estado de libertad y plenitud absolutos (mokșa, mukti).

Para entrar en materia conviene recordar que contra la imagen romántica de la India, no es inusual encontrar en la historia del pensamiento indio la sospecha de que la liberación sea, en última instancia, un estado negativo. Se alberga, pues, la duda de que lo que se cree que es supremo, después de todo no lo sea tanto, que haya siempre algo más. Encontramos así intentos de presentar la liberación como un logro que debe negarse a sí mismo o por lo menos replantearse continuamente con el fin de asegurar su perfección y carácter definitivo. Tal vez la forma más sencilla de ilustrar esta visión de una libertad perfectible sea recordando el radical giro que las doctrinas sobre la materia experimentarían hacia el final del primer milenio de nuestra era con el fin de legitimar formalmente la posibilidad de una salvación en vida (jīvanmukti), ahí mismo cuestionando el carácter último de la libertad post mórtem (videhamukti). ${ }^{37}$

Como en todo lo demás, la aportación de Abhinavagupta a esta añeja sospecha consistirá en llevar la misma hasta sus últimas consecuencias a través de un desmantelamiento sostenido del discurso soteriológico tradicional. Con base en diferentes estrategias retóricas, entre ellas el uso de metáforas como bhitti, ese desmantelamiento a menudo se tradujo en una férrea resistencia a asignarle un valor definitivo o estable al concepto de liberación, extrapolando así el discurso apofático sobre el Absoluto al campo de la reflexión en torno al destino del hombre.

Entonces, en el contexto de su teoría estética, Abhinavagupta emplea el término bhitti para describir el carácter distintivo de śánta rasa, el «sabor» estético de tranquilidad que, de acuerdo con él, subyace a todos los sentimientos y emociones que un ser humano puede experimentar. Sin pretender un recuento pormenorizado de los fundamentos teóricos sobre los que se erige la estética abhinavaguptiana, para nuestros fines baste aquí recordar que desde una época temprana la reflexión en torno a la creación literaria, en especial respecto al género dramático, mostró interés por el modo como las palabras pronunciadas sobre un escenario y acompañadas de gestos y otras expresiones corporales pueden desatar una emoción

\footnotetext{
${ }^{37} \mathrm{Si}$ bien los esfuerzos doctrinales de pensadores vedāntinos como Śañkara y Maṇḍana Miśra (siglo VIII), o textos como el Yogavāsiștha, contribuyeron a articular la soteriología del jūvanmukta, no parece incorrecto asumir que fueron las tradiciones tántricas de Cachemira las primeras que intentaron justificarla teóricamente. Desde luego, aunque el término es más bien tardío, la idea data de textos canónicos como la Bhagavadgītā y ciertas Upaniṣads. Al respecto puede consultarse L. Bansat-Boudon, op. cit., p. 32ss; asimismo E. Fort (ed.), Living Liberation in Hindu Thought, Nueva York, 1996, en especial los caps. 1-3, y G. Oberhammer, La délivrance, dès cette vie, París, 1994, caps. 2 y 4.
} 
estética. ${ }^{38}$ Así, el ya mencionado Nātyaśāastra (aprox. s. III-IV d. C.), cuyos argumentos se mantendrían fuera de toda duda por varios siglos, canoniza ocho emociones inherentes (sthayībhāvas) a la condición humana, y explica cómo a partir de la combinación de diversos factores (vibhāvas) cada una de estas emociones, una vez desarrollada plenamente, puede desencadenar la experiencia del rasa, literalmente el «sabor», que le es intrínseco. ${ }^{39}$ Es justo a Abhinavagupta a quien debemos la adición de una novena modalidad: śānta-rasa o la experiencia estética de reposo, desarrollada a partir de un profundo conocimiento de sí (àtmavidyā). Como apenas mencioné, Abhinavagupta irá más lejos al afirmar que esta experiencia de paz o reposo es la que de hecho subyace a las demás, en virtud de su estrecha relación con la libertad espiritual (mukti). ${ }^{40}$

Así las cosas, en el argumento que lleva a la conclusión de que «el conocimiento de sí» (ātmavidyā) es el «sentimiento básico» (sthāyiz-bhāva), el «muro» (bhitti), que permite deleitarse estéticamente no sólo en śänta rasa sino de hecho en cualquier otro rasa, Abhinavagupta afirma:

Conocer la verdad no es sino conocerse uno mismo (ātmajñanna), conocerse a sí mismo tal como [se conoce] a un objeto particular. Pues si el ätman estuviese en efecto más allá, si fuese superior (para), no podría ser ätman (anātman). Mi maestro ha abordado el tema de manera extensa y yo mismo he abundado sobre ello en otra parte, por lo que no insistiré en lo mismo aquí. ${ }^{41}$

\footnotetext{
${ }^{38}$ En un principio, conforme a su marcada tendencia al formalismo, este interés se centró en elucidar la esencia de la emoción estética como algo que atañe a los protagonistas en un poema o en una pieza teatral, de modo que es «Rāma quien, por ejemplo, siente deseo (rati) por Sìtā, y, por lo tanto, es también Rāma (y no precisamente el lector o espectador del Rāmāyaṇa) quien se deleita con el sabor (rasa) erótico que sigue a su deseo» (cfr. S. Pollock, trad., Bouquet of Rasa and River of Rasa by Bhanudatta, Nueva York, 2008, p. xxxi). Sin embargo, un giro radical tuvo lugar en Cachemira a principios del siglo IX una vez que los especialistas en la materia, entre ellos el propio Abhinavagupta, comenzaron a prestar mayor atención al modo como el receptor de una pieza literaria experimenta él mismo un sentimiento estético, relegando a un segundo plano las antiguas preocupaciones formalistas. La innovación apunta, pues, a un énfasis en la recepción de la obra de arte y no tanto en su producción: ¿cómo puede la declamación de un poema o la representación de un drama desatar una experiencia estética en el escucha o espectador? ¿Cuál es el mecanismo que le permite a ese escucha responder a la emoción que el texto evoca? Preguntas como éstas permitieron la gradual fusión de dos teorías hasta ahora desarrolladas por separado: por un lado, la teoría sobre el sabor estético o rasa; por el otro, la teoría sobre el poder evocador o dhvani que caracteriza a la buena literatura.

${ }^{39}$ Véase Nātyaśāstra 6-7. Las ocho emociones básicas o sthaȳ̄bhāvas son: deseo (rati), alegría (hāsa), tristeza (śoka), ira (krodha), valentía (utsāha), repugnancia (jugupsā), asombro (vismaya), miedo (bhaya). Los factores o vibhāvas que permiten que estas emociones maduren o alcancen plenitud pueden ser «subyacentes» (älambana), «estimulantes» (uddīpana), «transitorios» o «secundarios» (vyabhicāri), así como toda clase de reacciones físicas y expresiones corporales (anubhāvas). Por último, los rasas o «sabores» resultantes son: erótico (șrngāra), cómico (hāsya), patético (karuna), iracundo (raudra), heroico (vīra), repulsivo (bībhatsa), asombroso (adbhuta) y terrorífico (bhayānaka).

${ }^{40}$ Como es de esperar, la validez de esta inclusión, que en buena medida responde a la posibilidad de vincular las experiencias estética y religiosa, no estuvo exenta de polémica, y hoy en día sigue siendo uno de los temas más debatidos entre los especialistas de la poética sánscrita.

${ }^{41}$ Abhinavabhāratī 8.108 en la edición de Baroda (Gaekwad Oriental Series): tattvajñānam ca nāma ātmajñānam eva. ātmanaśca vyatiriktasya vișayasyaiva jñānam paro hi evam àtmā anātmā eva syāt. vipañcitạn ca etad
} 
La desconcertante ${ }^{42}$ afirmación que he subrayado en itálicas (sánscrito: paro $h i$ evam àtma anātma eva syāt) parece moverse por el mismo cauce al que nos condujo nuestro análisis de bhitti en textos en apariencia de índole muy distinta. Lo que aquí parece afirmar Abhinavagupta es que el tipo de trascendencia de la que depende la estabilidad de śánta rasa —asegurándole su comparación con un «muro» (bhitti) - es, como en el caso del Absoluto, una trascendencia negativa. Para llegar a esta conclusión, sin embargo, Abhinavagupta va más allá y desdice la noción misma de âtman, poniendo en entredicho el sitio tan encumbrado que sin reservas le ha asignado la tradición. Se trata de una decisión sin precedentes, si bien justificadamente tántrica en su ánimo trasgresor. Si fuera «otro», si estuviera localizado «más allá» (para), el ātman no podría ser «esencia», «lo propio». Para cumplir con esa función definitiva, el âtman debe renunciar a su halo de exclusividad, negar su superioridad (para), volverse próximo al grado de confundirse incluso con la fachada siempre cambiante del universo, muy a la manera, de nuevo, como una pared o un lienzo (bhitti) se confunde con las texturas, colores y formas plasmados sobre su superficie. Esta vuelta a lo inmanente, articulada a través del recurso de la negación, es lo que salva al àtman de la idolatría de lo remoto, de ser no más que la abstracción que llamamos esencia o alma.

Desde luego, el ātman no es un objeto como los demás. Empero, para Abhinavagupta tal certeza resulta insuficiente, pues se corre el riesgo de reducir el alma a una sustancia colocada en el ápice de la escala del ser, en la cima de la identidad personal, y en tanto tal limitada por la idea misma de jerarquía. Es pues necesario pensar el âtman bajo una óptica distinta, trasladar su significado a un entorno diferente, más dinámico. Partiendo de tan imperiosa necesidad, la respuesta a la pregunta por la esencia del hombre descansaría en un conocimiento que es al mismo tiempo una retracción. Y si, de acuerdo con Abhinavagupta, el conocimiento del $\bar{a} t m a n$ supone de entrada redefinir el valor superlativo de la noción misma de ātman, se sigue que la liberación tampoco podrá equivaler a un estado último, superior (para).

Así las cosas, sin una meta fija que alcanzar, la invitación al auto-conocimiento, de la que depende la salvación, se revela como una tarea nada sencilla y casi absurda. A imagen y semejanza de la esencia divina, la esencia del hombre descansa en la paradoja de una superioridad que se niega a sí misma una y otra vez a fin de asegurar su eminencia. Al recurrir en ambos casos a la imagen de un muro, indirectamente Abhinavagupta confirma la identidad de este par de núcleos apofáticos, mimetizados el uno en el otro desde sus entrañas vacías, desde su inasible infinitud, como un espejo frente a otro.

asmadgurubhih. asmābhiś ca anyatra vitanyata itżha na atinirbandhah kṛtah. «Yo mismo he abundado sobre ello en otra parte», nos recuerda Abhinavagupta. Hasta donde sé nadie ha identificado ese otro texto. ¿Pudiera tratarse de su Breve exégesis al Parätrīsikī Tantra?

42 Clumsy («confusa», «atropellada») la llamaron Masson y Patwardhan, op. cit., p. 130, n. 5. Para un tratamiento distinto de la misma expresión véase K. Bhattacharya, «Sāntarasa et Advaita», Journal Asiatique 260 (1972), pp. 89-105, y E. Gerow, art. cit., pp. 186-208. 


\section{CONCLUSIONES}

En este ensayo he revisado el significado de una imagen poco común e incluso toda una rareza dentro de la literatura religiosa y filosófica de la India para describir la naturaleza última de la divinidad y el ser humano: un muro o lienzo (sánscrito, bhitti). Como vimos fue Abhinavagupta quien dio a la imagen una fuerza expresiva sin paralelo en concordancia con sus propias premisas doctrinales, en particular su apuesta por una visión dinámica y en última instancia apofática de la realidad divina, el cosmos y la salvación. Desde esta perspectiva, lejos de ser secundaria o ingenua, la imagen de un muro acaba siendo un recurso clave dentro de una retórica metafórica como la de Abhinavagupta consagrada a reformular y, más todavía, llevar hasta sus últimas y paradójicas consecuencias el ideario de la no dualidad (advaita), de modo que lo trascendente y lo inmanente se confundan el uno en el otro tal como sucede con el fondo homogéneo (sama) y la superficie variopinta (citra) de una pared (bhitti). 